\title{
Finding Florence
}

\section{Florence Nightingale and Hospital Reform: Collected Works of Florence Nightingale, Volume 16 \\ Lynn McDonald, editor \\ Wilfrid Laurier University Press, 2012}

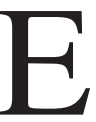
veryone knows of Florence Nightingale, but what do they actually know about her? Most might respond only that she was the "lady with the lamp" who helped create the concept of the modern nurse. In fact, there is an astonishing amount of information that one could learn about her, because she left a staggering amount of material about her long life and her work.

Nightingale was born in 1820 in the Italian city of Florence (hence her name) and died in London in 1910. She has been the subject of numerous biographies, ranging from the hagiographic to the highly critical. In 1913, shortly after her death, the standard "official" biography appeared; about 40 years later, Cecil Woodham-Smith published a glowing account of Nightingale's life that has endured but is not wholly reliable. Beginning in the 1980s, studies of Nightingale turned nasty. F.B. Smith's Florence Nightingale: Reputation and Power (1982) set the tone for an era of supposed mythbusting and historical exposé, along with what some might call sexist commentary: Florence Nightingale was no longer cast as angelic, but more like Margaret Thatcher with attitude and also a personality disorder. A 2008 biography by Mark Bostridge strove to present Nightingale in a more reasoned historical light, but that attempt took over 600 pages.

Restoration of historical equilibrium for Florence Nightingale ultimately has come from Canada's University of Guelph through Lynn McDonald, now university professor emerita in the

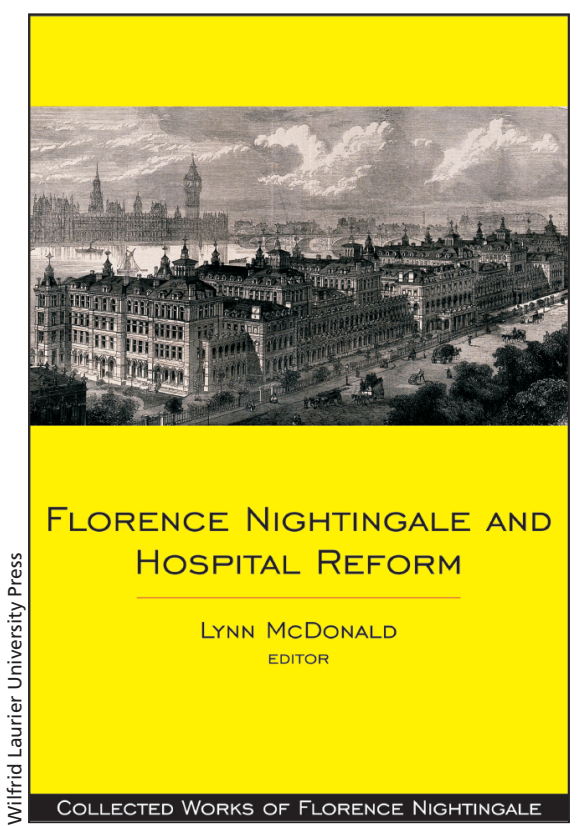

Department of Sociology and Anthropology. As well as being a noted social scientist, McDonald was also a member of parliament during the 1980s and is a former president of the National Action Committee on the Status of Women. McDonald was inspired to undertake the megaproject of editing and publishing all of Florence Nightingale's surviving documents; to do so, she surveyed material from over 150 institutional and personal collections around the globe. The Collected Works project has finally amounted to 16 volumes, each of which is about 1000 pages. In tandem with this project, McDonald has published extensively, adding to the historiography of Nightingale, including probably the best guide to her life, Florence Nightingale at First Hand (2010).

Florence Nightingale and Hospital Reform, the final volume in the series, maintains the high scholarly, editorial and publishing standards set for this project. It is in five sections, the first and last of these containing material helpful to scholars, including an introduction, details of the micro- and macro-editing process, an appendix of biographical sketches and a bibliography. Section 2 consists of the first, second and third editions of Notes on Hospitals (1858, 1859 and 1863, respectively). Bringing together these works in sequence permits analysis of Nightingale's evolving thoughts on hospital reform at this formative stage of her career. The third section, on military hospitals, includes a miscellany of notes, article and reports motivated by "her own experience of the horrendous defects in British Army hospitals during the Crimean War." But it is the fourth section, with over 400 pages, that is the heart of Hospital Reform; it describes civil hospitals for the period 1858 to 1895 in locations such as Australia, Canada (Montréal, Quebec), Malta, Portugal, Scotland (Glasgow), Wales (Bangor, Swansea) and England (Buckinghamshire, Derby, Hampshire, London, Liverpool and the Midlands), along with institutions as varied as general, fever, children's, convalescent, cottage and women's hospitals.

Nightingale's comments regarding the Montreal General and Royal Victoria hospitals in Montréal reveal her typical forthrightness, prudence and concern for proper hospital design and the well-being of nursing staff: "I do most solemnly say, don't commit yourself to Montreal on any such understanding as this," she wrote in 1874 to Maria Machin, a Canadian nurse chosen to become the matron of a proposed new Montreal General. Nightingale was right, for the planned hospital never materialized, some nurses died in the old building, and the remainder, including Machin, returned to England. Fourteen years later, Nightingale critiqued aspects of Saxon Snell's architectural plan for the Royal Victoria based on her integrated and holistic conception of the role of the nurse, hospital traffic flow, and ventilation and 
cleanliness: "Do not you think that, if the first plan is difficult of administration and supervision, the sketch with the double corridor and divided wards is almost impossible, without any commensurate sanitary or other advantage? ... No matron could supervise it, while every ward must have a responsible sister, because the essence of supervision is that the sister should see her whole ward from one point."
The team of McDonald and Wilfrid Laurier University Press is to be commended for this scholarly contribution. Medical, nursing and military historians, undergraduate and graduate students, and scholars of gender and Victorian studies will find these volumes of use, as will university, public and health science libraries (the books are also available in electronic format). There are many monuments to Florence
Nightingale, but surely the Collected Works project is among the most informative and enduring of them all.

\section{J.T.H. Connor PhD}

John Clinch Professor of Medical

Humanities and History of Medicine

Faculty of Medicine

Memorial University

St. John's, NL

CMAJ 2014. DOI:10.1503/cmaj.131439 